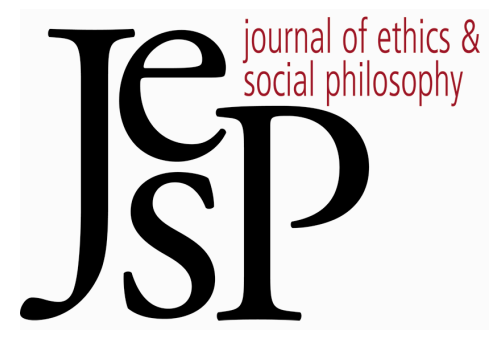

\title{
Four SOLUTIONS To THE ALLEGED INCOMPLETENESS OF VIRTUE ETHICS
}

BY SEAN MCALEER 


\title{
Four Solutions to the Alleged Incompleteness of Virtue Ethics Sean McAleer
}

\begin{abstract}
STANDARD MODE OF ARGUMENT in moral philosophy is to $A$ argue that an ethical theory should be rejected because it counts as 1 right what is intuitively wrong or as wrong what is intuitively right that, like a logical system from which one can derive theorems that are false, the theory is unsound.
\end{abstract}

In "Virtue and Right," Robert Johnson seems to make just this sort of argument against virtue ethics, arguing that "the claim that right actions are those of a virtuous person is ... utterly false." 1 But he can, I think, more profitably be read as making a different sort of argument against virtue ethics, that, like a logic which cannot generate all logical truths as theorems, virtue ethics is incomplete, since there are moral requirements (e.g., duties of moral selfimprovement) that cannot be derived from it:

.... any theory that relies on [the claim that right actions are those of a virtuous person] to construct a virtue-oriented theory of right action will be unable to explain moral distinctions we regularly make regarding behavior appropriate for those who could better themselves. ${ }^{2}$

\section{Virtue Ethics and the Charge of Incompleteness}

When pressed for an account of right action, virtue ethicists will often respond with something like the following:

Virtuous Agent Agent $A$ 's $\phi$-ing in circumstances $c$ is right iff a fully virtuous agent, acting characteristically, would $\phi$ in $c .^{3}$

As Rosalind Hursthouse is at pains to remind us, standards like Virtuous Agent need to be filled in with a substantive account of what the virtues are and what a virtuous person is like, just as a consequentialist standard needs to be filled in with a substantive account of what the best consequences are, etc. ${ }^{4}$ Johnson assumes that, however Virtuous Agent is fleshed out, there will

1 Robert Johnson, "Virtue and Right.” Ethics 113 (2003): 810-34; p. 810.

2 Johnson, p. 810

3 Cf. Johnson's criterion $\mathrm{V}$, which reads:

An action $A$ is right for $S$ in circumstances $C$ if and only if a completely virtuous agent would characteristically A in C. (812)

I offer Virtuous Agent instead of $\mathrm{V}$ to avoid the suggestion that rightness is relativized to agents, since an action's being "right for $\mathrm{S}$ " might suggest that the action that is right for $\mathrm{S}$ might not be right for similarly circumstanced $S^{*}$. This is obviously not Johnson's intention - his argument would make little sense if he relativized rightness in this way - and his inspiration for $\mathrm{V}$, the standard Rosalind Hursthouse offers in On Virtue Ethics (New York: Oxford University Press, 2001), p. 28, does not so relativize rightness.

${ }^{4}$ Hursthouse, pp. $28 f f$. 
be things that those of us who are not fully virtuous - whom I shall call the subvirtuous ${ }^{5}$ - ought to do in order to improve ourselves morally. But since a fully virtuous person would not characteristically perform any of the actions required of the subvirtuous, none of these actions can be right according to Virtuous Agent, so virtue ethics is incomplete. A completely virtuous and thus temperate agent can safely navigate the dangers of the ice cream aisle without falling into gluttony; I, on the other hand, had best stay away, as my desire for Ben \& Jerry's Chubby Hubby will likely get the better of me. A completely virtuous and thus honest person would not keep and reflect upon a list of the lies she tells in order to become more honest, but this may be just what a subvirtuous person should do. ${ }^{6}$ Since a fully virtuous person would neither avoid morally fraught situations nor take positive steps away from vice and toward virtue, the subvirtuous person's duty to do so cannot be generated from Virtuous Agent - and thus virtue ethics is incomplete.

The charge of incompleteness bedevils not just contemporary virtue ethics but its historical antecedents, as well. Consider Aristotle's attitude toward shame (aidôs), for instance. Despite the suggestion that shame is a virtue - the cause of political courage is a virtue, since its cause is shame ${ }^{7}$ - Aristotle's official view is that shame is not a virtue, but even so it is conditionally good: "if one were to do disgraceful actions, one would feel disgrace," course the antecedent is never fulfilled for a virtuous person. But just as continence falls short of virtue but is morally preferable to incontinence, so shame is not a virtue but is morally preferable to shamelessness. Remembering that our emotions no less than our actions are morally evaluable for Aristotle, when I act wrongly I ought to feel shame. But since the fully virtuous person would not act wrongly and thus will not have done anything to be ashamed of, how can an Aristotelian virtue ethics, construed somewhat anachronistically as accepting Virtuous Agent, ground the rightness of a subvirtuous agent's feeling shame?

In what follows I briefly discuss Valerie Tiberius' response to Johnson's charge of incompleteness and then offer four solutions of my own. The first, inspired by Judith Jarvis Thomson's negative approach to virtue ethics, replaces Virtuous Agent with a vice-grounded criterion of wrongness, an upshot of which is that not engaging in acts of moral self-improvement is wrong. The second, inspired by Julia Driver's work on suberogatory actions, retains Virtuous Agent but appeals to what I call countererogatory actions, actions that are wrong but nonetheless good to do, and holds that self-improving actions are countererogatory. The third draws on the ethics of the great ancient Chinese philosopher Mengzi and replaces Virtuous Agent with a standard couched in

${ }^{5}$ I thank Matthew Brophy for this way of putting it.

${ }^{6}$ Johnson, pp. 816-8.

7 NE III.8 1116a27-8. All references to Aristotle are to the Nicomachean Ethics (abbreviated NE), cited by book, chapter, and Berlin number. Translations are by T. Irwin, Aristotle: Nicomachean Ethics (2nd ed.), (Indianapolis: Hackett Publishing, 1999).

8 NE IV.9 1128b29-30; my italics. 
terms of Mengzi's cardinal virtues, the most salient of which is the virtue of righteousness, which can ground duties of self-improvement and thus avoid incompleteness. The fourth response, inspired by Christine Swanton's work on the virtues as modes of response to value, rejects Virtuous Agent in favor of a standard that holds an action right iff it respects, expresses or promotes virtue; since self-improving action promotes the agent's virtue, this kind of virtue ethics is not incomplete.

\section{Valerie 'Tiberius' Response to Johnson}

Valerie Tiberius suggests that we respond to Johnson's challenge by opting for a criterion of right action couched in terms of the fully virtuous person's reasons for action rather than what a fully virtuous person would do in the circumstances. ${ }^{9}$ That is, she would replace Virtuous Agent with

Reasons A's ping in $c$ is right iff $\phi i n g$ is the action in accordance with the reasons that would guide the action of a completely virtuous person in $c$.

For example, a virtuous person tells the truth even when doing so is against her interests "[f]or the sake of fostering good communication and treating others with respect." 10 A subvirtuous person such as Johnson's habitual liar can also act on this reason while performing actions (such as keeping a list of the lies he continues to tell) that the virtuous person would emphatically not perform.

This is an intriguing proposal, interesting in its own right and as a response to Johnson's challenge. It can succeed only if "the right action for the non-virtuous person could be different from the right action for the virtuous person even though both act for the same reasons." 11 Tiberius argues that this condition is met since "the virtuous person's reasons include the ideal of self-improvement" just as the subvirtuous person's do or can, since "the fully virtuous agent is concerned about the development and upkeep of her character." 12 I worry that developing or acquiring something - be it a fortune, proficiency in Italian, or a virtue - differs enough from maintaining it that the virtuous and subvirtuous agents do not act on the same reason in a sufficiently robust sense. In the interests of space - and in full knowledge that what I say here will not do justice to Tiberius' fine paper - I shall confine myself to one brief objection. Following Hume's advice "not to draw our philosophy from too profound a source," 13 let us consider the television pro-

9 Valerie Tiberius, "How to Think About Virtue and Right." Philosophical Papers 35 (2006): 247-65.

10 Tiberius, p. 251.

11 Tiberius, p. 252.

12 Tiberius, p. 253.

13 David Hume, "Of the Standard of Taste" in E. Miller, ed., David Hume: Essays Moral, Political, and Literary, rev. ed. (Indianapolis: Liberty Classics, 1987), p. 234. 
gram Dexter, in which the title character and his step-sister, Deb, share commitments to justice and to making their city safer. But to say that their actions on these shared reasons are different would be to drastically understate matters: Dexter is a principled serial killer who seeks out as victims criminals who have escaped punishment, while Deb is a police detective who seeks to put her murderous step-brother behind bars - though in a de re rather than de dicto sense. The problem is not just that Reasons sanctions Dexter's murderous activity - though that would be a pretty big problem; the problem is that the notion of a reason for action has been stretched too thin to be of much use if actions as different as these can flow from the same reasons. Much will depend on how reasons for action are specified, but they must be rather coarsely grained to do the work Tiberius requires of them, and this raises problems similar to the problems about maxim-specification that beset Kant's ethics: the more coarsely grained the reason or maxim is, the more likely it is that Reasons will yield moral falsehoods; the more finely grained the reason is, the less likely it is that virtuous and subvirtuous agents will share it.

\section{The Vicious Agent Solution}

My first solution picks up on a suggestion of Judith Jarvis Thomson's to go negative, so to speak, and "look at the virtues ... because of the importance of their contraries, the vices, to supplying an account of what morality requires us to do." ${ }_{14}$ So, rather than defining right conduct as what the fully virtuous person would do in the circumstances à la Virtuous Agent, we define wrong conduct thus:

Vicious Agent A's $\phi$-ing in circumstances $c$ is wrong iff a fully vicious agent, acting characteristically, would $\phi$ in $c$.

So, rather than requiring that I emulate the virtuous person, morality requires that I avoid being like the vicious person.

Note how well this negative approach comports Aristotle's ideas about moral development. All neo-Aristotelians can repeat in their sleep the dictum that "we become just by doing just actions and become temperate by doing temperate actions," 15 which suggests that the path of moral self-improvement is to follow Virtuous Agent. But Aristotle also suggests a "second best" mode of moral development: "steer clear of the more contrary extreme ... [and] take the least of the evils." 16 This path of moral improvement is not to do what the virtuous person would do but to come to virtue indirectly, by doing what the less vicious person would do: to aim to be rash rather than cowardly, prodigal rather than ungenerous, vain rather than pusillanimous (but

${ }^{14}$ Judith Jarvis Thomson, "The Right and the Good.” Journal of Philosophy 94 (1997): 273-98, p. 286.

15 NE II.4 1105a18-20.

16 NE II.9 1109a31-35. 
self-deprecating rather than boastful), etc. Leaving aside the practical question of whether this advice is efficacious, ${ }^{17}$ it raises the incompleteness problem for theories accepting Virtuous Agent, for it tells the subvirtuous person not to do what the virtuous person would do. But a theory grounded in $\mathrm{Vi}$ cious Agent can avoid the charge of incompleteness: a fully vicious person would not act to improve herself, so, since one must not act as she does, the subvirtuous must engage in moral self-improvement. Perhaps this will be a two-stage process: first, one follows the "second-best tack" and moves from more vicious to less vicious; at stage two, one avoids doing what the partly or less vicious agent would do. While Virtuous Agent can account for only the second step, a suitably tweaked version of Vicious Agent can account for both.

Those who do not share Thomson's minimalist and negative conception of what morality requires of us may find Vicious Agent's negative focus on avoiding badness and wrongdoing to be at odds with an Aristotelian emphasis on achieving excellence. But Aristotle's remarks about choice in NE II.3 suggest that this via negativa can find a home in an Aristotelian framework. The virtuous person acts for the sake of to kalon - what is fine or noble or (morally) beautiful. It is often the presence or absence of this motivation, not the action performed, that distinguishes virtuous from vicious conduct. For example, sometimes the vulgar person does not spend more than the magnificent person but rather spends in the wrong way: her aim is not to do what is fine, but to display her wealth and to gain admiration from others. ${ }^{18}$ While the virtuous person characteristically is motivated by to kalon, sometimes she acts to avoid what is base or shameful - e.g., the brave person "stands firm because that is fine (kalon) or because anything else is shameful (aischron)." ${ }_{19}$ The best person is attracted by what is noble or fine rather than her own advantage or pleasure, but second best is the person who is repulsed by what is shameful. So Aristotle himself makes room for avoiding what is shameful as a proper, if second-best, motivation.

Since Vicious Agent requires that one avoid acting as the vicious agent would, and since the vicious agent would not seek to improve herself morally, it is wrong not to take steps to avoid vice. Thus Vicious Agent can ground duties of moral self-improvement, and an ethics adopting it as its standard of right conduct would not be incomplete.

\section{The Countererogatory Solution}

The next solution is inspired by Julia Driver's work on suberogatory actions. ${ }^{20}$ Rather than tweaking or replacing Virtuous Agent, this solution instead introduces a new category with which to make sense of Virtuous Agent's deliver-

17 For an excellent discussion of this question, see Howard Curzer, "Aristotle's Bad Advice about Becoming Good." Philosophy 71 (1996): 139-46.

18 NE IV.2 1123a24-6.

19 NE III.7 1116a10-2.

${ }^{20}$ Julia Driver, “The Suberogatory.” Australasian Journal of Philosophy 70 (1992): 286-295. 
ances. Most of us are familiar with supererogatory actions: actions that are permissible (but not required) that are nonetheless especially praiseworthy and good. For example, moved by news of a stranger's need for a kidney, I offer her one of mine. I am not required to do so - I would not act wrongly in not donating a kidney - and my doing so is especially good and worthy of praise. Less familiar, perhaps, are suberogatory actions, actions that are permissible but bad to do. Driver offers as an example my not giving a kidney to my best friend or brother: other things being equal, I would not act wrongly if I did not donate a kidney, but my not doing so is plausibly seen as bad and worthy of condemnation, as it shows a failure of love on my part. ${ }^{21}$ Readers familiar with Thomson's famous "A Defense of Abortion" will be familiar with suberogatory actions, though perhaps not under that description. If the older of two brothers will not share the chocolates which he and his younger brother were given as a gift, he acts wrongly (and badly), since he deprives the younger brother of what he is entitled to. But if the chocolates belong only to the older brother and he selfishly will not share any, he does not act wrongly (they are bis chocolates, after all), though he acts badly: his not sharing the chocolates in these circumstances is suberogatory - not wrong but bad. ${ }^{22}$

In this spirit, imagine a more complex moral taxonomy that countenances not only supererogatory and suberogatory actions but also countererogatory actions: actions that are wrong - actions in which we fail to do what is morally required of us - but are nonetheless good to do. Here are three examples:

Smoker Winston is a two-pack-a-day smoker who cuts down to half a pack. He should not smoke at all, so even half a pack is impermissible, but all the same his progress is praiseworthy; Winston's smoking one of his ten cigarettes is wrong but good.

Vermeer Claude owns a Vermeer that he plans to destroy for no good reason, an action that would not be wrong but would be bad. Johannes seeks to prevent Claude's performing this suberogatory act and replaces the original with a copy, which Claude destroys. Johannes is wrong to interfere with Claude's enjoyment (if that is the right word) of his property, but it is good that he does so.

Prodigal Son Jack, the agnostic and prodigal son of Boughton, a Presbyterian minister, returns home after an absence of 20 years. To bring comfort to his dying father, he considers telling his father that he has found his faith. His lying to his father would wrong but good. ${ }^{23}$

The conduct in Smoker may strike some readers as raising a prudential rather than a moral issue. Perhaps, but even Kant thought that agents sometimes

${ }^{21}$ Driver, pp. 287-8.

22 Judith Jarvis Thomson, “A Defense of Abortion.” Philosophy and Public Affairs 1 (1971): 47-

66, pp. 56-61.

${ }_{23}$ Marilynne Robinson, Home (New York: Farrar, Straus and Giroux, 2008), pp. 264ff. 
have moral duties to promote their own well-being (e.g., a gout-sufferer), ${ }^{24}$ but since we tend in that direction naturally, the goad of duty is not typically required. ${ }^{25}$ But even if one remains doubtful about the example's content, it nicely illustrates the structure of countererogation. Vermeer exhibits an interesting connection between suberogatory and countererogatory acts, that to prevent a suberogatory act is (often) to perform a countererogatory act. Clearly this does not always hold; whether the prevention is countererogatory turns on whether it is good, and this depends crucially on the details of the case: forcing the brother in Driver's example to donate a kidney would be bad as well as wrong. As for Prodigal Son, some readers will regard Jack's misleading his father as permissible rather than wrong. But this is just the sort of case on which the countererogatory sheds light. Why not say instead that Jack would violate a norm of honesty and thus act wrongly, but that his lying would be good, given his reasons - and since the goodness of the action outweighs its wrongness, he ought to do it? Jack is trying to comfort his father, but if his reasons were self-interested (e.g., he is afraid of being disinherited), his lying would be both wrong and bad. Similarly, if the chocolates belong to both brothers and the older brother will not share because he wants more chocolate for himself, he acts wrongly and badly. But if he will not share the chocolates because he is genuinely concerned for his brother's health (perhaps his brother is diabetic) or because he knows his brother will be punished for eating too many chocolates before dinner, he acts wrongly, because he is depriving his younger brother of what he has a right to, but his act is nonetheless good.

Resistance to countererogation might come from the plausible but, in my view, mistaken assumption that deontic act evaluations are themselves action-guiding; that is, that once an agent knows an action is right or wrong, she knows enough to know that it ought (not) to be done. I hold that a deontic evaluation is but one factor with respect to action-guidance, not the whole story. I would not act wrongly in enforcing a contract that will be financially disastrous for you and superfluously beneficial for me, given my already immense wealth - but doing so would be bad, given its effect on you and what it says about my character. I would be deontically off the hook, so to speak, if I enforced the contract, but the deontic is but a part of morality, not its whole. Other considerations - e.g., the action's effect on others, one's motive(s), what the action says about one's character - must also be considered before one knows whether one should act, and the relations between these considerations may be complex and nuanced and not codifiable.

Another ground is a tendency to think that the connections between deontic notions such as rightness and wrongness and agathic notions such as good-

${ }^{24}$ Kant, Groundwork, 4:399. References to Kant's texts will be to the Prussian Academy pagination found in the margins of most translations. Translations are by Mary Gregor: Groundwork of the Metaphysics of Morals (New York: Cambridge University Press, 1998), Doctrine of Virtue (in Metaphysics of Morals) (New York: Cambridge University Press, 1996).

${ }^{25}$ Kant, Doctrine of Virtue, 6:386. 
ness and badness are conceptual rather than contingent. Typically, rightness and goodness run in the same harness: it is usually good to do what is right, and bad to do what is wrong. But suberogation shows that rightness and goodness can come apart: actions can be right but bad. Consider, moreover, the connections between rightness and praiseworthiness. Merely doing one's duty - by not shoplifting, by not tripping an annoying colleague as he passes one in the hallway, by returning library books when due - is not typically praiseworthy. But sometimes doing what is morally required is praiseworthy, as when it comes at a significant cost or when doing so is especially difficult. To continue heeding Hume's advice, consider the fictional mobster Tony Soprano, who, having learned that his daughter's high school soccer coach has been having sex with one of her teammates (who in turn is suicidal over it), struggles mightily and successfully against his desire to have the coach killed. As he drunkenly stumbles home, he tells his wife, "I didn't hurt nobody today." For Tony, not killing Coach Hauser is something of an accomplishment and - in his case - it merits praise. His doing his duty is praiseworthy, even though most cases of doing one's duty are not. Similarly, we tend not to think that failing to do what is morally required is praiseworthy, but it seems that there are many cases - typically cases of moral self-improvement - in which it makes sense to think of actions as both wrong and good.

Some will object that countererogation is counter-intuitive and too contorted. But given that virtue ethics takes character rather than duty to be the proper starting-place for ethical theorizing, we should not be surprised that novel categories are needed to make sense of the procrustean endeavor of fitting virtue ethics into a framework that modern ethical theories take for granted. Despite their obvious differences, Mill and Kant agree that the task of moral theorizing is to find a standard of right action. Mill tells us that that "[i]t is the business of ethics to tell us what are our duties, or by what test we may know them" 26 while Kant seeks an "infallible way ... to distinguish in every case that comes up ... what is in conformity with duty or contrary to duty." ${ }_{27}$ Given that this assumption is not shared by Aristotle or by many contemporary virtue ethicists, it should not be surprising that something like countererogation is needed to accommodate virtue ethics to the demands of modern moral thought.

With some of the oddness of the countererogatory hopefully blunted, consider one more example:

Selfish Ayn is wealthy and selfish, giving neither time nor money to alleviate human suffering despite her being well placed to do so. Having read Peter Singer, she sends $\$ 100$ to Oxfam, which, given her wealth, is far less than she can afford. Indeed, since it is far less than minimal generosity requires of her, Ayn fails to act rightly, but what she does is nonetheless good.

${ }^{26}$ Mill, Utilitarianism, G. Sher, ed. (Indianapolis: Hackett Publishing, 1979), p. 17.

${ }^{27}$ Kant, Groundwork, 4:403-4. 
Ayn does not act as a fully virtuous agent would, so by Virtuous Agent's lights she does not act rightly. Still, intuitively, her action is good; even though she falls below what virtue requires of her, she is moving toward it - and she ought to be praised and encouraged for doing so. Johnson's objection is that Virtuous Agent cannot account for the fact that Ayn is acting as she should. The countererogation strategy bites the bullet by conceding that Ayn's actions are not right but hopefully turns the bullet into a blank by holding that her actions are nonetheless good. Insofar as the agents are moving toward what the virtuous agent would do, their actions are good and merit praise which is both backward-looking, as all praise is, but also forward-looking, for it functions as encouragement as well.

\section{The Mengzian Solution}

The third solution to the alleged incompleteness of virtue ethics is inspired by the great ancient Chinese philosopher Mengzi (c. 372-289 BCE), perhaps better known by the Latinized form of his name, Mencius. Given Mengzi's attention to moral development, it will not surprise those familiar with his work that he may shed some light on Johnson's objection. In a famous passage in which he criticizes his contemporary Gaozi, Mengzi says:

Gaozi never understood righteousness (yz), because he regarded it as external. One must work at it, but do not assume success. One should not forget the heart (xin), but neither should one "help" it grow. Do not be like the man from Song ... a farmer who, concerned lest his sprouts not grow, pulled on them. Obliviously, he returned home and said to his family, "Today I am worn out. I helped the sprouts to grow." His son rushed out and looked at them. The sprouts were withered. Those in the world who do not "help" the sprouts to grow are few. Those who abandon them, thinking it will not help, are those who do not weed their sprouts. Those who "help" them grow are those who pull on the sprouts. Not only does this not help, but it even harms them. ${ }^{28}$

Even without accepting Mengzi's notion of sprouts as incipient tendencies to goodness, we can see his point: moral development, like physical development, can be stymied by attempting to do more than one is capable of. Just as a beginning cyclist will be harmed rather than helped by following Lance Armstrong's training regimen, a subvirtuous person who tries to do what the virtuous person would do is not only unlikely to improve but may indeed regress. I may not yet be able to extend my compassion, the sprout of be-

${ }_{28}^{28}$ Mengzi 2A2. References to Chinese texts - the Mengri, the Analects, the Zhongyong (rendered as Maintaining Perfect Balance or (more commonly) as The Doctrine of the Mean - will be by the traditional divisions of the texts into chapter and section. Translations cited are by Bryan Van Norden, tran., Mengæi (Indianapolis: Hackett Publishing, 2008); Roger Ames and Henry Rosemont, trans., The Analects of Confucius: A philosopbical translation (New York: Ballantine Books, 1998); Daniel K. Gardiner, tran., Maintaining Perfect Balance (in The Four Books) (Indianapolis: Hackett Publishing, 2007). 
nevolence, to suffering strangers, and I may stunt or stifle rather than nurture my moral development by overwhelming myself with information about their suffering. Perhaps I should not spend the weekend volunteering at the hospice, though my compassionate friend should do just that. I may need to do things before or during a department meeting that my virtuous, less irascible colleague need not do. If Johnson's habitual liar did not keep her lists and avoid dangerous situations, she would be like "those who do not weed their sprouts," while Mengzi insists on the need for "deep plowing and careful weeding." ${ }_{29}$

So, Mengzi holds there are things that the subvirtuous person ought to do that a fully virtuous person would not do and thus he seems implicitly aware of the incompleteness objection. What solution can Mengzi offer? The heart of the Mengzian response is to replace Virtuous Agent with a criterion couched in terms of Mengzi's cardinal virtues:

Mengzi A's ding in $c$ is right if and only if $A$ 's $\phi i n g$ in $c$ expresses benevolence $(r e n)$, righteousness $(y i)$, ritual propriety $(l i)$, or wisdom (zhi).

The virtue most relevant here is yi, usually translated righteousness, though we will see that it extends beyond the perhaps narrowly religious connotations of that term to something more akin to appropriateness. So, what is Mengzian righteousness? In the Confucian classic Maintaining Perfect Balance, righteousness $(y i$ (義)) is defined paronomastically as what is right or appropriate (yi (宜) $)^{30}$ - which Van Norden suggests "would probably be accepted by all Chinese thinkers." ${ }_{31}$ While yi often involves correct performance of ritual (li), it extends beyond a mere disposition to conform one's conduct to ritual, often functioning negatively as a side-constraint:

Yi Yin farmed the fields of the ruler of Xin and delighted in the way of Yao and Shun. If it was not righteous (yi), if it was not the Way (dao), even if you gave him the whole world as his salary, he could not consider it. Even if you gave him a thousand teams of horses, he would not glance at it. If it was not righteous, if it was not the Way, he would not give or accept from others so much as a twig. ${ }^{32}$

In the face of temptation, possessing the virtue of righteousness ensures that one's conduct conforms to the way, not just to the rites. Van Norden argues that "Righteousness is a disposition to accord with agent-relative prohibitions involving the expression and preservation of one's own ethical character ...

${ }^{29}$ Mengæi 1 A5.

${ }^{30}$ Zhongyong 20.5. Compare Ames and Hall's rendering: “Appropriateness means doing what is fitting" (Roger Ames and David Hall, trans., Focusing the Familiar (Honolulu: University of Hawaii Press, 2001).

${ }^{31}$ Bryan Van Norden, Virtue Ethics and Consequentialism in Early Chinese Pbilosopby (New York: Cambridge University Press, 2007), p. 257.

32 Mengzi 5A7; cf. 6A10. 
[W] can understand Mengzian righteousness as a sense of shame." ${ }_{33}$ Similarly, Kwong-Loi Shun suggests that "the attribute $y i$ involves disdaining and regarding as potentially tainting to oneself what falls below ethical standards, as well as an insistence on distancing oneself from such things, even if gravely undesirable consequences may result." ${ }_{34}$ Given that the heart or feeling (xin) of disdain (wu) is the "sprout" (duan) of righteousness (yi), it is not surprising to find righteousness functioning in this negative way, as a sort of deontological restriction.

But righteousness also functions positively. In distinguishing $y i$ and $l i$, Shun argues that " $y i$ has to do with whatever is appropriate to a situation, whether [or not] that behavior is an instance of some general rule [i.e., a ritual]." ${ }_{35}$ In a famous passage, Chunyu Kun reminds Mengzi that ritual propriety ( $l i$ ) prohibits men and women touching; hoping to trip Mengzi up, Chunyu Kun asks Mengzi if he would save his drowning sister-in-law by pulling her out with his hands. Mengzi's response is telling:

Only a beast would not pull out his sister-in-law if she were drowning. It is the ritual that men and women should not touch when handing something to one another, but if your sister-in-law is drowning, to pull her out with your hand is a matter of discretion (quan). ${ }^{36}$

While righteousness $(y i)$ is not mentioned explicitly here, it is lurking in the background, for righteousness and benevolence are what separate humans from beasts. ${ }^{37}$ While Mengzi does not explicitly connect discretion and righteousness, righteousness is often a disposition to see what a situation requires and to act accordingly. Sometimes this calls for avoiding conduct seen as shameful, but there are also spots along the path calling for positive, creative responses. Mengzi gives avoiding the shameful more play than achieving the morally beautiful, but there are occasional hints of the latter, as when, discussing one of the Odes, he speaks of the "beautiful virtue (yi de)" that provides a "norm (ze)" for "people [to] cleave to" 38 - a Mengzian analog of Aristotle's to kalon.

Mengzian $y i$ is in part, at least, a virtue of seeing what a situation calls for and acting appropriately, of being flexible. 39 While Zimo is praised for finding a mean between Yang Zhu's egoism and Mozi's impartiality, "if one holds to the middle without discretion (quan), that is the same as holding to one ex-

33 Van Norden, Virtue Ethics, p. 258-9.

${ }_{34}$ Kwong-Loi Shun, Mencius and Early Chinese Thought (Stanford: Stanford University Press, 1997), p. 62.

35 Shun, p. 57.

36 Mengzi 4A17.

37 Mengzi 6A8.

38 Mengzi 6A6.

39 Mengzi 6B3. 
treme." 40 There is a strong flavor of this in certain passages from Kongzi's (Confucius') Analects:

Exemplary persons (junz?) in making their way in the world are neither bent on nor against anything; rather they go with what is appropriate $(y z) .^{41}$

There were four things the Master abstained from entirely: he did not speculate, he did not claim or demand certainty, he was not inflexible ( $w u g u$ ), and he was not selfabsorbed. ${ }^{42}$

So, let us see what Mengzian righteousness, understood (in part) as a virtue of situational appropriateness, has to offer as a way of responding to Johnson's objection. If I am subvirtuous, taking certain measures - weeding my garden, so to speak - would be appropriate, whether these be making and reflecting on a list of my lies or avoiding the ice cream aisle at the grocery store. I ought to do these things, as they are expressions of the virtue of righteousness. The subvirtuous person is not doing what the virtuous person would do in those circumstances, but this is because the same virtue, righteousness, makes different demands on people at different stages or levels of moral development. What is righteous or appropriate depends not only upon the circumstances, but upon the nature of the agent, as well. Or, to put it another way: the circumstances the agent finds herself in comprise not just facts external to the agent but also her moral nature - what point she occupies in moral space, as it were, and the direction she is traveling (toward virtue, toward vice, etc.). One can imagine two agents who are equally subvirtuous, one of whom has an upward trajectory toward virtue, the other a downward trajectory toward vice. It may be appropriate for the former to challenge herself a bit, morally speaking, while the latter perhaps should just try to stop her moral decline. This is not to suggest that anything goes. If one steals a chicken every day from a neighbor, cutting down the thievery to one chicken a month would be a step in the right direction, but appropriateness requires that one stop stealing chickens altogether. ${ }^{43}$ Similarly, Johnson's habitual liar should stop lying. And to bring that about, she should also do things that the fully virtuous person would not do, such as becoming aware of the sorts of situations in which she tends to lie and avoiding or minimizing exposure to those situations until she is better equipped to face them. ${ }^{44}$

Let me consider two objections. The first, from within the Mengzian camp, so to speak, is that I have made Mengzi seem more latitudinarian than he is, and that my interpretation is graveled by passages such as this:

40 Mengzi 7A26.

41 Analects 4.10.

42 Analects 9.4.

${ }^{43}$ Mengri 3B8.

${ }^{44}$ The issues John Doris raises in "Persons, Situations, and Virtue Ethics" (Nô̂s 32 (1998): 504-30) will strike a chord with many readers here, though considering them is beyond the scope of this paper. 


\begin{abstract}
Mengzi's disciple Gongsun Chou said, “The Way is certainly lofty and fine (meı)! But it seems as if it mounts Heaven itself, so that it cannot be reached. Why not make it so that it can be reached and pursued earnestly every day?"

Mengzi replied, "A great carpenter does not warp the plumb-line for the sake of an inept worker. The great Yi did not change how he taught to draw the bow for the sake of an inept archer. A gentleman draws back the bow, but before he lets the arrow fly, he stands in the middle of the way: let those who are able follow him." 45
\end{abstract}

This suggests that the righteous or appropriate action is the action the virtuous person would perform, so we are right back to Johnson's objection. At least two responses are apropos. The first is that my primary interest here is not exegetical: the solution offered is small-m Mengzian - that is, inspired by Mengzi, not necessarily fitting every text. The second is that the passage in question does not really tell against the Mengzian response. This second response is threefold. First, consider an obviously related passage: "When the master archer Yi instructed people, they had to set their will on drawing the bow to the full. Those who learn must also set their will on 'drawing it to the full." "46 This suggests that those learning to shoot should have as their goal shooting as the skillful archer shoots, even if they currently lack the skill to do so. Read in light of 6A20, 7A41 tells us that the skillful archer or carpenter will not change the goal of instruction in order accommodate an inept or clumsy student, but this is consistent with instruction that accommodates the student's skill level. Secondly, 7A41 should be read in light of other passages in which Mengzi warns against the human tendency to confuse inability with unwillingness. Many of us are like King Xuan of Qi: confronted with our moral failings, we are apt to excuse them by appealing to our weaknesses or moral inabilities when in fact the problem is lack of will or desire to improve. The king thinks Mengzi's teachings are "excellent" 47 but lists his weaknesses: he is too fond of courage, ${ }^{48}$ wealth and sex ${ }^{49}$ to treat his subjects benevolently. But Mengzi's view is that the king is not unable to improve himself, he just does not do so..$^{50}$ We must not be like the man from Song, but we must not do nothing, either: "One cannot work with those who throw themselves away... Those who say, 'I myself am unable to dwell in benevolence and follow righteousness' are whom I mean by 'those who throw themselves away.." 51 Thirdly, Mengzian righteousness as comprising situational appropriateness is firmly rooted in the Confucian tradition, as this passage from the Analects attests:

45 Mengzi 7A41.

46 Mengzi 6A20.

47 Mengzi $1 \mathrm{~B} 5$.

48 Mengzi 1B3.

49 Mengzi 1B5.

50 Mengzi $1 \mathrm{~A} 7$.

51 Mengzi 4A10. 
Zilu inquired, "On learning something, should one act upon it?" The Master said, "While your father and elder brothers are still alive, how could you, on learning something, act upon it?" Then Ranyou asked the same question. The Master replied, "On learning something, act upon it."

Gongxi Hua said, "When Zilu asked the question, you observed that his father and elder brothers are still alive, but when Ranyou asked the same question, you told him to act on what he learns. I am confused - could you explain this to me?"

The Master replied, "Ranyou is diffident, and so I urged him on. But Zilu has the energy of two, and so I sought to rein him in." 52

What is appropriate depends not just upon the circumstances external to the agent, but on her moral nature, as well.

The second objection is that the virtue of righteousness construed as situational appropriateness is too open-textured and intuitionistic, so Mengzi is insufficiently action-guiding. Answering this objection is well outside the ambit of this paper, but we should note that this is not Johnson's incompleteness objection, but another objection altogether - what Gerasimos Santas calls the "stock modern objection to Aristotelian ethics, as old as Grotius" ${ }_{53}$ - which besets Virtuous Agent as much as it besets Mengri. While this is not an objection that a virtue ethicist can ignore, it is not an objection to Mengzi ias a solution to the incompleteness of virtue ethics.

The Mengzian solution is to replace Virtuous Agent with Mengri. Even when their external circumstances are identical, what is appropriate for a virtuous and a subvirtuous person might be different; so long as the subvirtuous person acts appropriately, she acts rightly, by Mengzi's lights. Her selfimproving actions are required by Mengzi, so this kind of virtue ethics is not incomplete.

\section{The Promotion Response}

The last solution I offer draws its inspiration from Christine Swanton's understanding of the virtues as ways of responding to value. ${ }^{54}$ Swanton distinguishes four primary responses: honor or respect, promotion, expression, and appreciation, calling these different modes of response the profiles of the virtues and noting that some virtues are plural in having more than one profile. Roughly speaking, one honors or respects value $V$ by not acting against it by not acting un- $V$-ly. A pacifist takes respect to be the profile appropriate to the value peace: one appropriately responds to it by not acting violently (i.e., unpeacefully). One honors friendship by not acting in an unfriendly way, perhaps by helping a friend move even when one temporarily lacks warm

52 Analects 11.22.

53 Gerasimos Santas, “The Structure of Aristotle's Ethical Theory.” Topoi 15 (1996): 59-80, p. 61.

${ }^{54}$ Christine Swanton, "Profiles of the Virtues." Pacific Philosophical Quarterly 76 (1995): 47-72; Christine Swanton, Virtue Ethics: A Pluralistic Approach (New York: Oxford University Press, 2003). 
feelings toward one's friend. One promotes a value by acting so as to make more of it, whether maximally or satisfactorily. A just war theorist takes promotion to be the profile appropriate to peace and seeks to produce more of it, even if promoting it requires that one fail to honor it. Similarly, one could promote the value friendship by increasing the number of one's friendships. As Michael Stocker showed with respect to friendship, one can act from a value as well as toward it or for its sake. ${ }^{55}$ When the value is one's motive for acting, one's acting from that value expresses the value. So, moved by warm personal feelings, I may help a friend move as a natural expression of friendship, without regarding it as a duty that friendship imposes on me and without having more numerous or strengthened friendships as a goal. Kant and Mill would agree that duty is a value to be respected, though they disagree about what values underlie duty and what responses are appropriate to what is fundamentally valuable. Mill of course thinks that happiness is ultimately valuable and that it is a value to be promoted: "actions are right in proportion as they tend to promote happiness." ${ }_{56}$ Kant thinks that autonomy or moral personhood is ultimately valuable and is a value not to be promoted it is not an "object to be acquired by our action" 57 - but rather to be respected: it is "an end itself... the supreme limiting condition of the freedom of action of every human being." ${ }_{58}$ But an even more distinctively Kantian thesis involves expression as a response to value, for Kant thinks that only dutyconforming conduct done from duty is morally good: morally good action must not only respect duty, it must also express it. Aristotle seems to have the respecting-expressing distinction in mind in this well-known passage:

Hence actions are called just and temperate when they are the sort that a just or temperate person would do. But the just and temperate person is not the one who merely does these actions, but the one who also does them in the way (bôs) in which just or temperate people do them. ${ }^{59}$

The distinction also animates this perhaps less well-known passage on the distinction between natural virtue and virtue proper: "it is not merely the state in accord with the correct reason (kata ton orthon logon), but the state involving the correct reason (meta tou orthou logou), that is virtue." 60

With this background in place, let us turn to the fourth solution, replacing Virtuous Agent with:

55 Michael Stocker, "Values and Purposes: The Limits of Teleology and the Ends of Friendship," Journal of Philosophy 78 (1981): 747-65.

56 Mill, p. 7.

${ }^{57}$ Kant, Groundwork, 4: 428.

58 Kant, Groundwork, 4: 430-1 (italics original).

59 NE II.4 1105b5-9.

60 NE VI.13 1144b26-7. 
Virtue Promotion Agent $A$ 's $\phi$-ing in circumstances $c$ is right iff $A$ 's $\phi$-ing respects, promotes, or expresses the virtue most relevant to $c{ }^{61}$

Presumably, the fully virtuous agent's actions always respect the relevant virtue: the virtuous agent can be counted on to act in accordance with what the relevant virtue requires, whether the relevant virtue's primary profile is promotion, as is the case with generosity, or expression, as is the case with love, or respect, as is the case with honesty. But what of those actions that the subvirtuous agent should perform that the virtuous agent would not, such as avoiding the ice cream aisle or keeping a list of one's lies? Avoiding the ice cream aisle does not respect or conform to temperance, but neither is it an instance of intemperance, as would be eating a quart of ice cream in one sitting. Instead, avoiding the ice cream aisle promotes temperance. While the habitual liar's continuing to lie is contrary to and thus fails to respect honesty, her making her list and discussing it promotes honesty, making her likelier to someday be able to conform her conduct to its demands. Since Virtue Promotion can account for duties of moral self-improvement, a Virtue Promotiongrounded virtue ethics is not incomplete.

Even without considering the incompleteness objection, Virtue Promotion has an inclusivity that Virtuous Agent lacks. Given the plurality of profiles, why count as right only actions that respect (i.e., conform to) virtue? Consider Michael Slote's sentimentalist virtue ethics, according to which "an act is morally acceptable if and only if it comes from good or virtuous motivation involving benevolence and caring (about the well-being of others)," ${ }_{62}$ or an ethic according to which an act is right iff it expresses love. The crucial difference between such expressive standards of rightness and canonical standards such as Virtuous Agent is not that the former omit counterfactual reference to a virtuous exemplar but that they count as right only conduct that expresses (and does not merely respect or conform to) the relevant virtue. For such standards, doing what the virtuous person would do would at best be a necessary condition of right conduct; one would also have to act as the virtuous agent acts - which elides the Aristotelian distinction between virtuous acts and virtuous agents and in doing so raises the moral bar considerably.

An advantage of theories that take expression to be the fundamental response to value is they are not self-effacing, since they allow no distinction between justifying and motivating reasons; thus they pose a counter-example to Simon Keller's claim that virtue ethics, like deontology and consequentialism, is self-effacing. ${ }^{63}$ Indeed, it is not just that the theories in question are

${ }^{61}$ Given that Virtue Promotion includes other profiles as well (especially expression), it might seem infelicitously named, but as promotion is the profile most relevant in this response to Johnson's objection, I hope the infelicity will be forgiven.

62 Michael Slote, Morals from Motives (New York: Oxford University Press, 2001), p. 38.

63 Simon Keller, "Virtue Ethics is Self-Effacing," Australasian Journal of Philosophy 85 (2007): 221-31. 
not self-effacing, they could not be self-effacing: since proper motivation is the right-making feature of conduct, it is impossible for the motivating reasons to come apart from the justifying reasons, which is at the heart of the problem of self-effacement. But while self-effacement may be a theoretical vice, its opposite - what to call it? self-aggrandizement? - is not thereby a virtue, since self-aggrandizing theories may seem psychologically unrealistic, fail to accommodate the commonsense intuition that one can do the right thing for the wrong reason, and imply that an agent might act wrongly even though she performs the same action as an agent who acts rightly. But the issue here is not the plausibility of views such as Slote's but rather that Virtuous Agent does not accommodate theories taking expression to be the primary response to value, and since Virtue Promotion can accommodate such theories, Virtue Promotion is ceteris paribus preferable to Virtuous Agent.

Since self-improving actions promote virtue - in particular, the agent's virtue - Virtue Promotion would not fall prey to the incompleteness objection. Now, in addition to its being more inclusive than Virtuous Agent, Virtue Promotion counts among its virtues an organic relation to Aristotle's virtue ethics, in particular its pointing to a second sense of 'right', though not the sense Johnson discusses. Johnson notes that some defenders of Virtuous Agent wish to distinguish "right' as fully adequate" from "right' as morally excellent" and argue that the duties of moral self-improvement are captured by this "second-best" sense of 'right', but he argues that self-improvement is not merely acceptable or adequate, so rightness-as-adequacy "would not be a very plausible addition," 64 and virtue ethics remains incomplete. Let us grant this and go another route, drawing on a distinction that is near and dear to Aristotle's heart - the distinction between $x$ 's being $F$ with and without qualification (haplôs) - and distinguish between an action's being right without qualification, as when the action is such as a virtuous agent would do in the circumstances, and an action's being right in a qualified sense, as when it is right for this particular agent since it promotes (the agent's) virtue. ${ }^{65}$ The distinction permeates the Nicomachean Ethics, applying to good judges, ${ }^{66}$ knowledge, ${ }^{67}$ ends, ${ }^{68}$ being unaffected, ${ }^{69}$ anger, ${ }^{70}$ willingness, ${ }^{71}$ complete virtue, ${ }^{72}$ incontinence, ${ }^{73}$ vice, ${ }^{74}$ lovability, ${ }^{75}$ friendship, ${ }^{76}$ and pleasure. ${ }^{77}$ To take a more specific

${ }^{64}$ Johnson, p. 825.

${ }^{65}$ I thank Matt Walker for suggesting this as a naturally Aristotelian way of responding to Johnson's objection.

${ }_{66}$ NE I.3 1094b28-1095a2.

${ }^{67}$ NE I.4 1095b2-4.

68 NE I.7 1097a33-4, VI.2 1139a35-b5.

69 NE II.3 1104b18-26.

${ }^{70} \mathrm{NE}$ II.5 1105b32-6a1.

${ }^{71}$ NE III.1 1110a9-11.

72 NE V.1 1129b25-31, V.1 1130a8-13.

${ }_{73}$ NE VII.3 1146b19-21, VII.4 1147b20-3, VII.4 1147b31-8a5, VII.4 1148b4-14, VII.5 $1149 \mathrm{a} 21-4$.

${ }^{74}$ NE VII.5 1149a16-20. 
example, deliberation is good without qualification (haplôs) when it correctly promotes the unqualified end (to telos to baplôs) and is qualifiedly good when it promotes some limited end (pros ti telos). ${ }^{78}$ Moreover, "what is good may be good in either of two ways, as good without qualification (haplôs) or as good for some particular thing or person (tini)." ${ }_{79}$ Why not, then, speak of rightness in a qualified as well as an unqualified sense? Throwing goods overboard is not choiceworthy in itself and without qualification (since "when we speak of something without qualification (baplôs), we speak of it in itself (kath' bauto)" ${ }^{80}$ ), but it is choiceworthy in certain circumstances. ${ }^{81}$ The person who is incontinent about honor is not incontinent without qualification (since incontinence has the same range as intemperances2 but is incontinent in a metaphorical sense (kata metaphoran), ${ }^{83}$ which we flesh out by specifying the condition or qualification (prostithentes) ${ }^{84}$ of her incontinence. Similarly, my avoiding the ice cream aisle is not right or temperate without qualification (haplôs) but rather in a qualified sense: it is right on this occasion (tônde), given my current moral state; it is right not because it accords with (kata) or expresses (meta) virtue but because it promotes (pros) virtue. Not only do the qualified and unqualified senses of 'right' avoid the objections Johnson urges against the fully adequate and morally excellent senses, but they also have a textual warrant these other senses lack, and they capture the situational sensitivity and agent relativity that many find attractive in virtue ethics. Moreover, Virtue Promotion's unifying three profiles yields a more comprehensive standard of right action than Virtuous Agent.

Before closing, I should respond to an objection that reprises a standard objection to utilitarianism. My murdering a dozen bestially vicious people would result in a greater balance of virtue over vice and thus would promote virtue; according to Virtue Promotion my actions are right, but of course they are not, so Virtue Promotion must be false. At least two responses can be made here. First, one could go agent-relative, so to speak, and restrict the virtue being promoted to the agent's virtue (or, more particularly, to one or more of the agent's virtues), rather than virtue haplôs. Such a restriction is implicit in expression: the conduct does not express virtue simpliciter, it expresses the agent's virtue - who else's could it be? But there is no such agent-relativity implicit in conduct that respects or conforms to virtue, since in such conduct it is not the agent's virtue (or one of her virtues) to which conduct must con-

75 NE VIII.2 1155b17-25.

${ }^{76}$ NE VIII.4 1157b1-5.

77 NE VIII.5 1157b26-7.

78 NE VI.9 1142b28-31.

${ }^{79}$ NE VII.11 1152b26-7.

${ }^{80}$ NE VII.9 1151b2-3.

${ }^{81}$ NE III.1 1110b1-4.

82 NE VIII.3 1146b20-1.

83 NE VII.5 1149a21-4.

${ }^{84}$ NE VII.4 1147b33, VII.4 1148b13. 
form but rather an idealized agent's virtue(s). So there seems to be a bit of disunity in Virtue Promotion. But given the distinction between $x$ 's being $F$ with and without qualification, there is a happy symmetry in the fact that the virtue to be promoted is virtue in a qualified rather than an unqualified sense, since the agent acts to promote her own virtue, not virtue per se. The second response is to emend Virtue Promotion to include a prohibition on acting viciously, e.g.,

Virtue Promotion Plus Agent $A$ 's $\phi$-ing in circumstances $c$ is right iff $A$ 's $\phi$-ing respects, promotes, or expresses the virtue most relevant to $c$ and does not respect, promote, or express a relevant vice

Or, one could add instead, "and is contrary to no virtue." 85 Note that this sort of response is open to the virtue ethicist in a way that is closed off to the utilitarian, who cannot restrict the promotion of goodness by appealing to justice or right (e.g., by ruling out evil pleasures), given her commitment to the theoretical primacy of goodness. In adopting Virtue Promotion Plus, the virtue ethicist does not import a "foreign" concept that constrains her favored concept but instead remains within her favored family of concepts and takes one virtue to condition or constrain another.

So, the more comprehensive normative standard captured by Virtue Promotion grounds a virtue ethics that is not incomplete, since it can ground the duties of moral self-improvement that Virtuous Agent could not.

\section{Conclusion}

Johnson's incompleteness objection presents a serious challenge to virtue ethics. I have here offered four ways in which a virtue ethicist might respond. Johnson considers several responses to his objection: $(i)$ the "second-best" mode of rightness, discussed above; (ii) adopting an advice- rather than an examplar-model of virtue ethics, which makes rightness turn not on what the virtuous agent would do in the circumstances but on what she would advise one to do in the circumstances - though here he worries that while the virtuous person is sensitive to her circumstances, there is no reason to think she is thereby sensitive to others' circumstances or that she has any "explicit knowledge of moral rules (if there are any)" "86 that she could pass along or use to explain her advice; $;$ and (iii) "giving up on developing a theory of right altogether." 88 While some virtue ethicists advocate (iii) - most famously

85 Phillipa Foot, Virtues and Vices (Berkeley and Los Angeles: University of California Press, 1978), p. 14.; cf. Gary Watson, "On the Primacy of Character" in O. Flanagan and A. O. Rorty, eds., Identity, Character and Morality (Cambridge: MIT Press, 1990.), p. 445.

86 Johnson, p. 823.

${ }^{87}$ Hursthouse is especially vulnerable here, since she holds that "[v]irtue must surely be compatible with a fair amount of inarticulacy about one's reasons for action." Hursthouse, p. 127.

88 Johnson, p. 829. 
Anscombe - it seems a mistake to give up on rightness so soon. An ethics that can or chooses to say nothing about which actions are right and which wrong would be really incomplete. The solutions I offer here are promising; none of them is perfect - what positions in philosophy ever are? - but they show that the virtue ethicist has more arrows in her quiver than Johnson has perhaps allowed. ${ }^{8}$

Sean McAleer

University of Wisconsin - Eau Claire

Department of Philosophy and Religious Studies

mcalees@uwec.edu

89 This paper grew out of a National Endowment for the Humanities Summer Seminar, Traditions in Dialogue: Confucianism and Virtue Ethics, led by Stephen Angle and Michael Slote, at Wesleyan University in the summer of 2008. I thank the NEH for its support and thank Steve and Michael, and all the seminar participants, but especially Matt Walker and Howard Curzer, for a philosophically rewarding summer. Earlier versions of this paper were presented to a department colloquium at the University of Wisconsin - Eau Claire, the Pacific Division meetings of the American Philosophical Association in April 2009, and the Minnesota Philosophical Society in November 2009. I thank the audiences on those occasions (especially Valerie Tiberius and Ian Stoner at the MPS) and my commentators, David Wong at the APA and Matthew Brophy at the MPS, for very helpful comments and discussion. Thanks to my colleagues Ned Beach for comments on an earlier version of this paper, Scott Lowe for discussion of Mengzi and for his chairly support of my sabbatical, and Kristin Schaupp for invigorating discussions of super-, sub- and countererogation. I thank Eric Hutton for organizing the APA session and inviting me to present. I thank JESP's anonymous referees for helpful and encouraging comments. Work on this paper was generously supported a University Research and Creative Activity grant from the University of Wisconsin Eau Claire in the spring of 2009 and by the University of Wisconsin - Eau Claire Faculty Sabbatical Leave Program for the academic year 2009-2010, for which I am most grateful, with special thanks to Karen Havholm, Assistant Vice Chancellor for Research at UWEC, for so ably administering those programs. Last but not least, I thank Erica Benson for helpful comments on earlier drafts and for her support generally. 